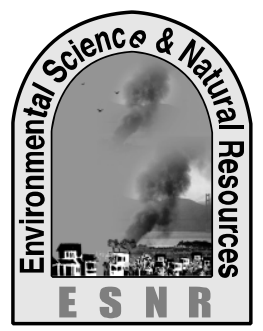

\title{
Assessment of the Quality of Industrial Wastewater in Three Metropolitan Cities in Bangladesh
}

\author{
N. Sultana ${ }^{1}$, H. Muktadir ${ }^{1}$, M. A. H. Chowdhury ${ }^{2}$ and M. A. Baten ${ }^{1 *}$ \\ ${ }^{1}$ Dept. of Environmental Science, ${ }^{2}$ Dept. of Agricultural Chemistry, \\ Bangladesh Agricultural University, Mymensingh-2202 \\ *Corresponding author: baten_envsc@yahoo.com
}

\begin{abstract}
This study was conducted to assess the quality of different industrial wastewater. Some physicochemical parameters viz., $\mathrm{pH}$, EC, TDS, $\mathrm{Na}^{+}, \mathrm{K}^{+}, \mathrm{Ca}^{++}, \mathrm{Mg}^{++}, \mathrm{CO}_{3}{ }^{2-}, \mathrm{HCO}_{3}{ }^{-}, \mathrm{Cl}^{-}, \mathrm{SO}_{4}{ }^{2-}, \mathrm{PO}_{4}{ }^{3-}$ including heavy metal contents like $\mathrm{Pb}, \mathrm{Cd}, \mathrm{Ni}, \mathrm{Cr}, \mathrm{As}, \mathrm{Zn}$ and $\mathrm{Cu}$ concentration from collected wastewater samples were analyzed. Atomic Absorption Spectrophotometer was used for analyzing the heavy metals in the wastewater samples. The results revealed that, the values of $\mathrm{pH}$, EC, TDS ranged between 6.44-9.0, 471-4307 $\mu \mathrm{S}$ $\mathrm{cm}^{-1}, 1952-5209 \mathrm{mg} \mathrm{L}{ }^{-1}$, respectively. The higher mean concentrations of $\mathrm{Na}^{+}, \mathrm{K}^{+}, \mathrm{Ca}^{++}, \mathrm{Mg}^{++}, \mathrm{CO}_{3}^{-}, \mathrm{HCO}_{3}^{-}, \mathrm{Cl}^{-}, \mathrm{SO}_{4}{ }^{2-}, \mathrm{PO}_{4}{ }^{3-}$ were $1407.8,27.9,69.9,76.6,2.7,11.7,1688,76.6,6.1 \mathrm{mg} \mathrm{L}^{-1}$, respectively. The mean concentration of $\mathrm{Cd}, \mathrm{Ni}, \mathrm{Cr}, \mathrm{Zn}$, and $\mathrm{Cu}$ was 0.17 , 0.87, 85.73, 0.80, and $1.56 \mathrm{mg} \mathrm{L}^{-1}$, respectively. Among trace elements $\mathrm{Ni}$ and $\mathrm{Cd}, \mathrm{Zn}$ and $\mathrm{Cd}, \mathrm{Zn}$ and $\mathrm{Cr}$ showed a positive relationship. To avoid the harmful effects of wastewater on environment it is imperative to treat industrial effluents before discharge into open environment.
\end{abstract}

Key words: Correlation, Heavy metals and Industrial wastewater

\section{Introduction}

With the rapid population growth, industrialization and urbanization processes also expand day by day. After 1971, Bangladesh is slowly and steadily turning its attention to develop its economy, through industrial development and moving away from the agricultural sector. The wastewater generated by large population and by industry is a major source of pollution. Even after treatment, wastewater can end up in areas deemed sensitive for the environment or human health. Industrial wastewater not only contains trace elements ( $\mathrm{Pb}, \mathrm{Cd}, \mathrm{Ni}, \mathrm{Cr}, \mathrm{As}, \mathrm{Zn}, \mathrm{Cu}, \mathrm{Hg}, \mathrm{Mn}$ ) but also bears excess amounts of cation $\left(\mathrm{Ca}^{++}, \mathrm{Mg}^{++}, \mathrm{K}^{+}, \mathrm{Na}^{+}\right)$ and anion $\left(\mathrm{SO}_{4}{ }^{2-}, \mathrm{NO}_{3}{ }^{-}, \mathrm{PO}_{4}{ }^{3-}, \mathrm{Cl}^{-}, \mathrm{CO}_{3}{ }^{2-}, \mathrm{HCO}_{3}{ }^{-}\right)$which are responsible for polluting water, even it inhibits plant growth. It is reported that among all the trace elements, chromium is the most widely used and discharged to the environment from different sources. Mercury, $\mathrm{Pb}$, $\mathrm{Cd}, \mathrm{Zn}$ and As are very toxic to living organisms. They can lower reproductive success, prevent proper growth and development; even cause death.

Though the growth of economy and the internal development of a nation depend upon the development of industrial sector but these sectors are responsible to pollute the natural environment due to discharge of untreated solid and liquid waste. As a result, pollution of water and soil environment increased day by day due to rapid industrialization (Anwar et al., 2006).

For example, 270 registered tanneries are located in Hazaribagh; these tanneries generate 7.7 million liters of liquid waste and 88 million tons of solid waste every day (Blacksmith Institute, 2007). The tannery industries are operating and discharging solid and liquid wastes directly to the low-lying areas, river and natural canals without proper treatment. Unfortunately, these discharges destroy the ecosystem of water and soil environment.

Zahir and Ahmeduzzaman (2012) reported that tanneries in the Hazaribagh area discharge some 21,600 cubic meters of liquid waste every day (RPMC, 2008). Another study observed that Tejgaon industrial area alone dispose about $12,000 \mathrm{~m}^{3}$ untreated industrial wastes per day, which consists variety of industrial units like soap, dyeing, pharmaceuticals, metals etc (Annual bulletin Tejgaon Upazila, 2003). The wastes of this industrial area are directly discharged into the drainage system or canal.

The main objectives of this paper were

i) to examine the physico-chemical constituents $(\mathrm{pH}$, EC, TDS, $\mathrm{Na}^{+}, \mathrm{K}^{+}, \mathrm{Ca}^{++}, \mathrm{Mg}^{++}, \mathrm{Cl}^{-}, \mathrm{SO}_{4}{ }^{2-}, \mathrm{PO}_{4}{ }^{3-}$ ) of different industrial wastewater, and (ii) to study the trace elements $(\mathrm{Pb}, \mathrm{Cd}, \mathrm{Ni}, \mathrm{Cr}, \mathrm{As}, \mathrm{Zn}$, and $\mathrm{Cu})$ of these samples.

\section{Materials and Methods}

\section{Study area}

Gazipur district located in between $23^{\circ} 53^{\prime}$ and $24^{\circ} 21^{\prime}$ north latitudes and in between $90^{\circ} 09^{\prime}$ and $92^{\circ} 39^{\prime}$ east longitudes, Hazaribagh situated in $90^{\circ} 21^{\prime}$ east longitudes and $23^{\circ} 45^{\prime}$ north latitudes and location of Mymensingh district is in between the latitudes $24^{\circ} 15^{\prime}$ and $25^{\circ} 15^{\prime}$ North and $90^{\circ} 05^{\prime}$ and $90^{\circ} 50^{\prime}$ East longitudes (Fig. 1).

\section{Sample collection}

Wastewater samples were collected from the drainage system of five types of industries where industrial effluents were discharged. To conduct this research two dyeing, two pharmaceuticals, two leather, two foods, and two plastic industries were considered. Sample size was 30 with three replicates. 


\section{Sample preparation}

After collection, all water samples were filtered through Whatman No.1 filter paper to remove unwanted solid and suspended material to avoid any undesirable situation during chemical analysis. Five to six drops of liquid toluene were added to control microbial growth. Then the samples were preserved in the laboratory at controlled temperature $\left(-18^{\circ} \mathrm{C}\right)$.

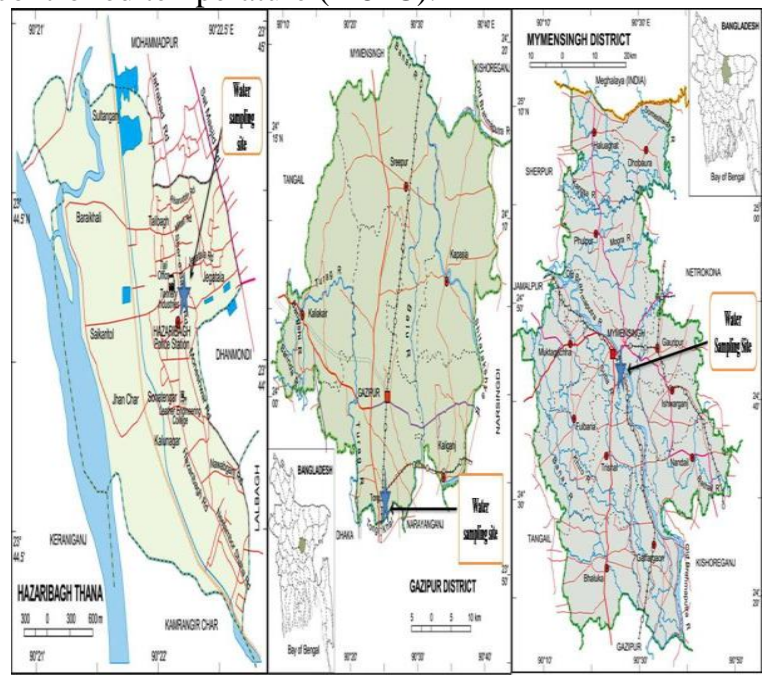

Fig. 1. Map of the study area

\section{Chemical analyses of wastewater}

Analyses of the physicochemical properties like $\mathrm{pH}$, EC, TDS, $\mathrm{Na}^{+}, \mathrm{K}^{+}, \mathrm{Ca}^{++}, \mathrm{Mg}^{++}, \mathrm{CO}_{3}{ }^{2-}, \mathrm{HCO}_{3}{ }^{-}, \mathrm{Cl}^{-}, \mathrm{SO}_{4}{ }^{2-}$ and $\mathrm{PO}_{4}{ }^{3-}$ of wastewater samples were conducted in the laboratory of Agricultural Chemistry, BAU. The concentrations of trace elements $(\mathrm{Pb}, \mathrm{Cd}, \mathrm{Ni}, \mathrm{Cr}$, As, $\mathrm{Zn}$, and $\mathrm{Cu}$ ) in wastewater samples were analyzed by atomic absorption spectrophotometer (Spectr AA-55B) at the Soil Science Division, Bangladesh Agricultural Research Institute (BARI), Joydevpur.

\section{Results and Discussion}

\section{pH, EC and TDS values}

The mean values of $\mathrm{pH}, \mathrm{EC}$ and TDS was found in wastewater of different industries are given in Table 1. According to the results, the values of $\mathrm{pH}, \mathrm{EC}$, TDS ranged between 6.44-9.0, 471-4307 $\mu \mathrm{S} \mathrm{cm}^{-1}, 1952-5209$ $\mathrm{mg} \mathrm{L}^{-1}$, respectively. Among the five different industries, wastewater of dyeing industry contains higher $\mathrm{pH}$ values 9.0 and wastewater of leather industry contains higher EC and TDS values of $4307 \mu \mathrm{S} \mathrm{cm}^{-1}$ and $5209 \mathrm{mg} \mathrm{L}^{-1}$, respectively. The use of sodium carbonate and salt in the dyeing process and electrolytes in the bleaching process causes an increase in EC of the wastewater (Mountassir et al., 2013).

Kamal et al. (2015) who found almost similar $\mathrm{pH}$ value (9.7) like this study in dyeing industry. According to Uddin (2004), the EC value of industrial wastewater was within the range of 288 to $7766 \mu \mathrm{S} \mathrm{cm}^{-1}$. Kamal et al. (2015) also found an excess TDS value $(9140.8 \mathrm{mg}$ $\left.\mathrm{L}^{-1}\right)$ in his study.

\section{Cations and anion contents}

The data presented in Tables 1 shows that cations were higher, in wastewater of leather and dyeing industries than those of the other industries. In tannery effluent, $\mathrm{Na}^{+}, \mathrm{K}^{+}, \mathrm{Ca}^{++}$, and $\mathrm{Mg}^{++}$varied from 934-1973, 16.628, 21.4-83.8 and 48.6-119.9 $\mathrm{mg} \mathrm{L}^{-1}$ respectively. Whereas in dyeing effluent these cations varied, form 627-1961, 11.3-42.8, 42.0-83.2 and 23.0-65.8 $\mathrm{mg} \mathrm{L}^{-1}$, respectively. Higher concentrations of cations were

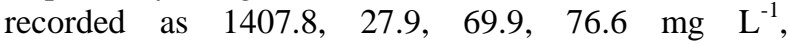
respectively. $\mathrm{Na}$ and $\mathrm{K}$ content of tannery and textile effluents were higher than the DoE standard for open water $\left[200 \mathrm{mg} \mathrm{L}^{-1}\right.$ for $\mathrm{Na}, 12.0 \mathrm{mg} \mathrm{L}^{-1}$ for $\mathrm{K}$ ] (DoE, 2003). Inorganic salt cations increase the salinity regime as well as electrical conductivity of water that is revealed in the present investigation. Among anion contents higher mean concentration of $\mathrm{Cl}^{-}, \mathrm{SO}_{4}{ }^{2-}, \mathrm{PO}_{4}{ }^{3-}$ was $1688,76.6,6.1 \mathrm{mg} \mathrm{L}^{-1}$, respectively. According to the results of Table 1, wastewater of leather industries contains higher load of $\mathrm{Cl}^{-}$and $\mathrm{SO}_{4}{ }^{2-}$ measuring 1588 and $76.6 \mathrm{mg} \mathrm{L}^{-1}$, respectively than wastewater of other studied industries. Hussain et al. (2004) reported that the $\mathrm{Cl}^{-}$content of four industries showed a discrepancy of 980 to $2185 \mathrm{mg} \mathrm{L}^{-1}$.

\section{Trace elements}

The mean concentration of $\mathrm{Cd}, \mathrm{Ni}, \mathrm{Cr}, \mathrm{Zn}$, and $\mathrm{Cu}$ was $0.17,0.87,85.7,0.80$, and $1.56 \mathrm{mg} \mathrm{L}^{-1}$, respectively (Fig. 2 and 3). Among the trace elements, higher concentration of $\mathrm{Cd}, \mathrm{Ni}$, and $\mathrm{Cu}$ was found in wastewater samples of dyeing industries where as the higher concentration of $\mathrm{Cr}$ was found in wastewater samples of leather industries. Heavy metals particularly, lead $(\mathrm{Pb})$, chromium $(\mathrm{Cr})$, Cadmium $(\mathrm{Cd})$, Copper $(\mathrm{Cu})$ and Nickel $(\mathrm{Ni})$ are widely used for the production of color pigments of textile dyes (Bhardwaj et al., 2014).

On the other hand, nearly $90 \%$ of all leather produced is tanned using $\mathrm{Cr}$ salts. Generally, $8 \%$ of the basic chromium sulphate salt is used for conventional tanning (Stein and Schwedt, 1994). This is the main reason for the higher concentration of trace elements $(\mathrm{Cd}, \mathrm{Ni}, \mathrm{Cu}$, and $\mathrm{Cr}$ ) in the effluents of dyeing and leather industry. Average contents of $\mathrm{Cd}$ and $\mathrm{Ni}$ in wastewater of different industries varied from 0.07 to 0.17 and 0.03 to $0.87 \mathrm{mg} \mathrm{L}^{-1}$, respectively (Fig. 2).

Wastewater samples of dyeing industries contained higher value of $\mathrm{Cu}$ concentration $\left(1.56 \mathrm{mg} \mathrm{L}^{-1}\right)$ from other industries (Fig. 3). Nazir et al. (2015) determined $\mathrm{Cd}$ concentration in dyeing industries was $0.129 \mathrm{mg} \mathrm{L}^{-1}$ which also exceeds the permissible limit like the present study. Among seven studied heavy metals, concentration of $\mathrm{Ni}$ and $\mathrm{Cu}$ slightly but $\mathrm{Cr}$ exceeded seriously the DoE recommended discharge standard in Bangladesh. Another trace element, $\mathrm{Cr}$ was found in wastewater of dyeing and leather industries at a higher concentration of 27.64 and $85.73 \mathrm{mg} \mathrm{L}^{-1}$, respectively (Table 1). Like this study, Husain et al. (2013) also found similar concentration of $\mathrm{Cu}$ in dyeing industries ranged from 0.15 to $1.08 \mathrm{mg} \mathrm{L}^{-1}$. 

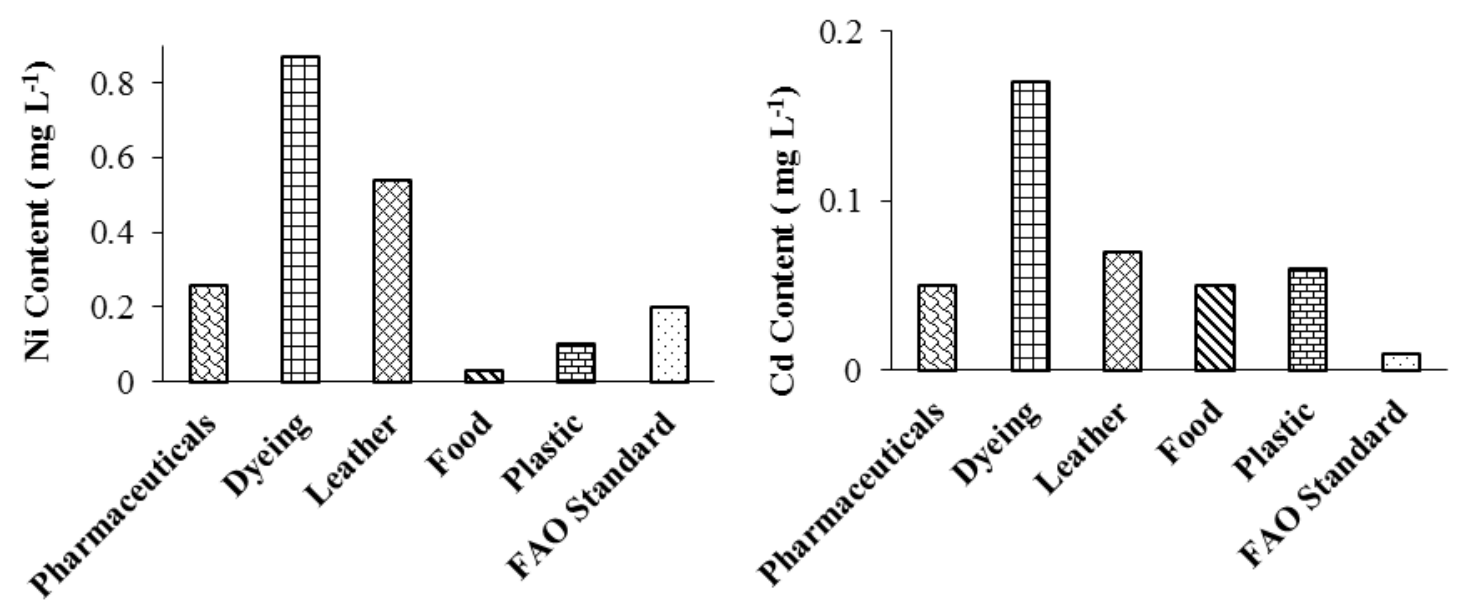

Fig. 2. Average $\mathrm{Cd}$ and $\mathrm{Ni}$ contents of different industrial wastewater

Table 1. pH, EC, TDS, Cations and anion content of different industrial wastewater

\begin{tabular}{|c|c|}
\hline Parameters & \\
\hline $\mathrm{pH}$ & Mean \\
\hline & Range \\
\hline $\mathrm{EC}$ & Mean \\
\hline$\left(\mu \mathrm{Sm}^{-1}\right)$ & Range \\
\hline TDS & Mean \\
\hline$\left(\mathrm{mg} \mathrm{L}^{-1}\right)$ & Range \\
\hline $\mathrm{Na}^{+}$ & Mean \\
\hline $\mathrm{Na}$ & Range \\
\hline $\mathrm{K}^{+}$ & Mean \\
\hline K & Range \\
\hline $\mathrm{Ca}^{++}$ & Mean \\
\hline & Range \\
\hline $\mathrm{Mg}^{++}$ & Mean \\
\hline & Range \\
\hline $\mathrm{Cl}^{-}$ & Mean \\
\hline & Range \\
\hline $\mathrm{SO}_{4}{ }^{2-}$ & Mean \\
\hline & Range \\
\hline $\mathrm{PO}_{4}^{3-}$ & Mean \\
\hline & Range \\
\hline $\begin{array}{c}\mathrm{Cr} \\
\left(\mathrm{mg} \mathrm{L}^{-1}\right)\end{array}$ & Mean \\
\hline
\end{tabular}

\section{Name of industries}

Pharmaceuticals

$$
7.57
$$

7.3-7.8

1896

434-3620

2200

1637-2617

984

737-1358

25.3

20.1-30.7

62.6

50.8-70.9

31.4

22.6-34.7

593

130-1335

31

87-188.5

2.4

1.6-3.5

1.2

$$
\text { Dyeing }
$$

9

8.7-9.3

4076

1517-6547

$\mathbf{5 0 5 5}$

4023-7033

1190.9

627-1961

27.9

11.3-42.8

69.9

42.1-83.3

$$
39
$$

23.1-65.8

973.4

144-1938

39

$77.2-274.3$

3.5

2.8-4.8

27.6
Leather

8.22

7.4-8.8

4307

2140-7210

$$
5209
$$

1213-8810

1407.8

934-1973

20.6

16.6-28

56.9

21.4-83.8

76.6

48.6-119.9

1588

524-2986.9

76.6

12.9-243.1

2.5

1.4-5.3

85.7
Food

6.4

6-7.2

471

301-560

1952

1867-2092

214.4

187-228

9.2

$8.7-9.8$

39.9

29.7-50.3

$\mathbf{1 7 . 8}$

15.1-23.6

49.0

42.0-55.7

45.5

100.8-120

5

4.7-6.7

0.16
Plastic

8.2

8.0-8.4

733

460-987

2892

1980-3843

329.3

$199-481$

$\mathbf{1 0 . 9}$

6.1-16.6

34.7

30.6-36.2

27.7

16.8-36.8

44.6

36.9-53.9

32.3

71.2-186.7

6.1

5.8-7.8

0.22
FAO

Standard 


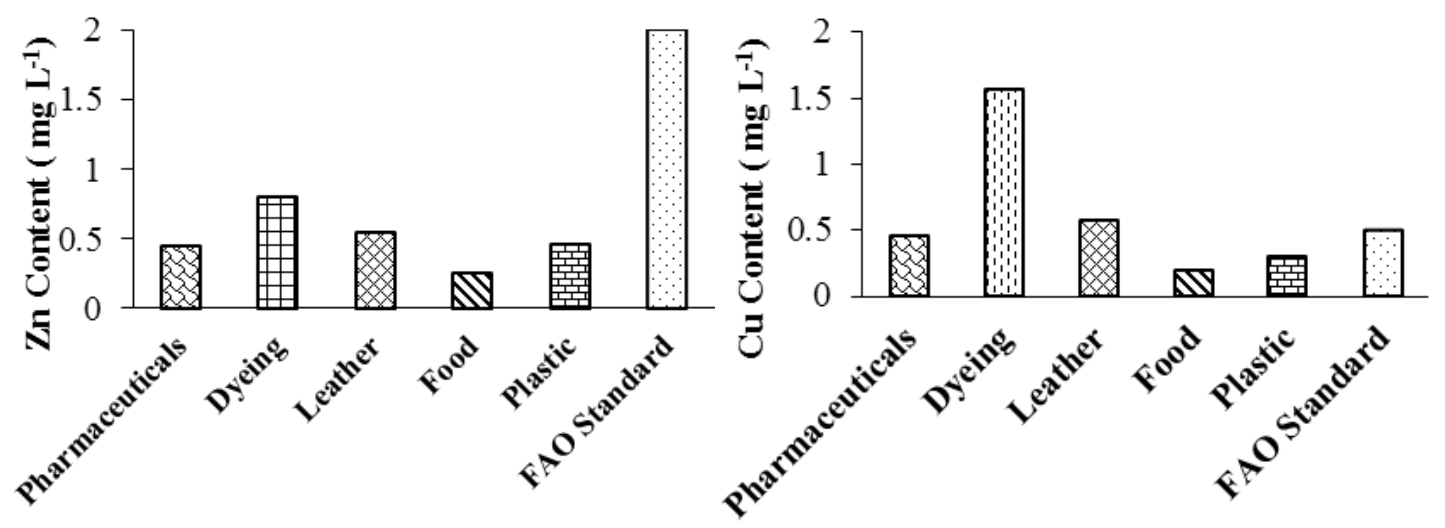

Fig. 3. Average $\mathrm{Zn}$ and $\mathrm{Cu}$ contents of different industrial wastewater

\section{Correlation analyses of trace elements}

Interrelationship studies between different water quality parameter are very helpful in understanding the geochemistry of the study area. The regression equation

$$
\text { A }
$$

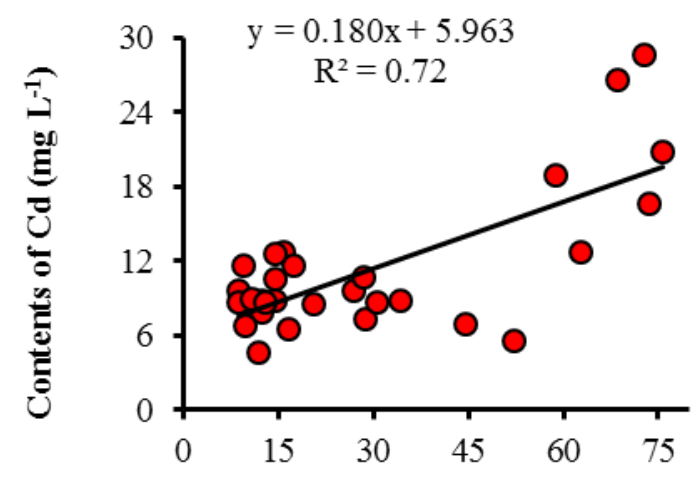

Contents of $\mathrm{Ni}\left(\mathrm{mg} \mathrm{L}^{-1}\right)$ for the parameter having significant correlation of other constitutes. The regression analysis has been done to find whether the relatioships among trace element parameters are linear or not (Fig. 4).

B

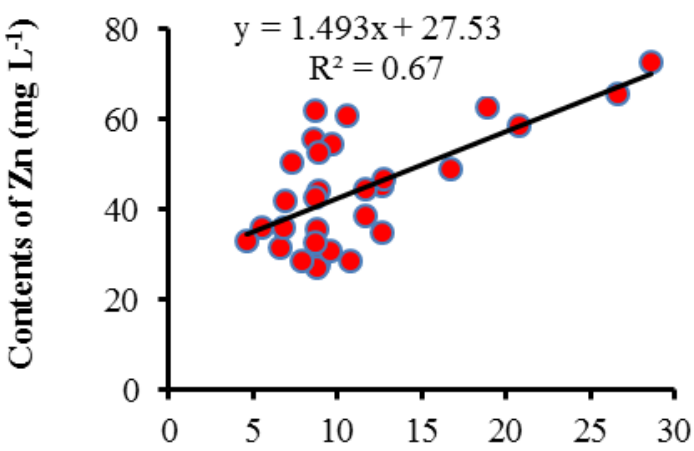

Contents of $\mathrm{Cd}\left(\mathrm{mg} \mathrm{L}^{-1}\right)$

C

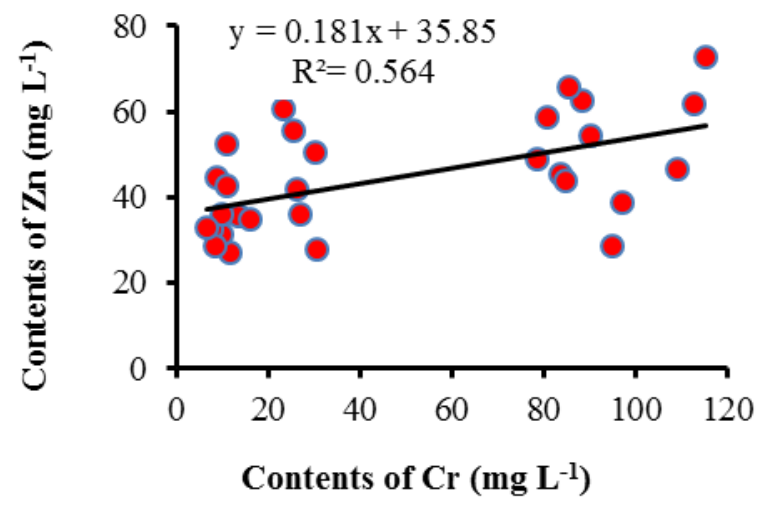

Fig. 4. Scatter plots between contents of $\mathrm{Ni}$ and $\mathrm{Cd}(\mathrm{A}), \mathrm{Zn}$ and $\mathrm{Cd}(\mathrm{B}), \mathrm{Zn}$ and $\mathrm{Cr}(\mathrm{C})$ of different industrial wastewater

\section{Conclusions}

This study concludes that wastewater of leather and dyeing industries contained excess EC, TDS, cations, anions, $\mathrm{Ni}, \mathrm{Cr}$, and $\mathrm{Cu}$ compared to other industrial wastewater. Higher concentration of trace elements in dyeing and leather industries, indicates that the wastewater of those industries could be more dangerous for the environment. Discharge of wastewater into environment without treatment should be strictly prohibited to avoid any unexpected hazards to protect the environment. 


\section{Acknowledgements}

The research was supported with the help of BINA, Laboratory of Agricultural chemistry, BARI and

\section{References}

Annual bulletin Tejgaon Upazila, 2002, 2011. Upazila agriculture extension office, (2002-2012), pp 5-15.

Anwar, T. B.; Alam, A. S. M. and Hossain, M. P. 2006. Industrial Sector of Bangladesh .Business Environment Final Term Paper. Institute of Business Administration, University of Dhaka.

Bhardwaj, V.; Kumar, P. and Singhal, G. 2014. Toxicity of Heavy Metals Pollutants in Textile Mills Effluents. International Journal of Scientific and Engineering Research, 5(7): 2229-5518.

Blacksmith Institute. 2007. The world's worst polluted places: The top ten of the dirty thirty. New York.

DoE (Department of Environment). 2003. A Compilation of Environmental Laws of Bangladesh.Administered by the Department of Environment.Second Reprint.

Hussain. J.; Hussain, I. and Arif, M. 2004. Characterization of textile wastewater. Journal of Industrial Pollution Control, 20(1):137-144.

Husain, I.; Husain, J. and Arif, M. 2013. Environmental impact of dyeing and printing industry of Sanganer, Rajasthan (India). Turkish Journal of Engineering and Environmental Sciences, 37: 272 -285.

Kamal, A. K. I.; Ahmed, F.; Hassan, M.; Uddin, M. K. and Hossain, S. M. 2015. Characterization of Textile Effluents from Dhaka Export Processing Zone (DEPZ) Area in Dhaka, Bangladesh. Department of Environmental Sciences, Jahangiragar University, Dhaka-1342, Bangladesh. Pollution, 2(2): 153-161.
Ministry of Science and Technology by providing funds.

Mountassir, Y.; Benyaich, A.; Rezrazi, M.; Berçot, P. and Gebrati, L. 2013. Wastewater effluent characteristics from Moroccan textile industry. Water Sci. Technol., 67(12): 2791-2799.

Nazir R. M. K.; Muhammad, M. and Hameed, U. R. 2015. Accumulation of Heavy Metals (Ni, Cu, Cd, $\mathrm{Cr}, \mathrm{Pb}, \mathrm{Zn}, \mathrm{Fe}$ ) in the soil, water and plants and analysis of physico-chemical parameters of soil and water Collected from Tanda Dam kohat. Journal of pharmaceutical sciences and research, 7(3): 89-97.

RPMC (River Pollution Mitigation Committee), 2008. Mitigation of River Pollution of Buriganga and linked rivers-Turag, TongiKhal, Balu, Sitalakhya and Dhaleswari. A report of RPMC, Dhaka. pp. 12-23.

Stein, K. and Schwedt, G. 1994. Chromium speciation in the wastewater from a tannery. Fresenius' Journal of Analytical Chemistry, 350: 38-41.

Uddin, M. M. 2004. Chemical and microbial characteristics of some industrial wastewater and their effects on the germination of Vignaasesquipedalis L. seed. An M.Sc thesis submitted to the Department of Agricultural Chemistry, Bangladesh Agricultural University, Mymensingh.

Zahir, H. and Ahmeduzzaman, M. 2012. A Case Study on The Impact of The Leather Industries on The Ground Water Aquifer in Bangladesh. International Journal of Civil and Environmental Engineering, 12(5). 